\title{
SANKSI ADMINISTRASI TERHADAP RETRIBUSI DALAM PELAKSANAAN PAJAK KENDARAAN BERMOTOR
}

\author{
DIAN NOVITA \\ Fakultas Hukum, Universitas Wiraraja Sumenep \\ dianovita79@yahoo.co.id
}

\begin{abstract}
ABSTRAK
Kebijakan-kebijakan dari pemerintah mengenai pajak diterbitkan agar penyelenggaraan pelayanan yang prima segera terealiasi. Keinginan tersebut setidaknya sejalan dengan apa yang mengenjala di ranah praktis, hampir seluruh pejabat publik, menjadikan isu pelayanan yang prima sebagai ikon kepemimpinan, apa yang terjadi tersebut kemudian mendapat dukungan teoritis. Reformasi birokrasi terus menguat karena tidak dapat dilepaskan dari pelaksanaan otonomi daerah di Indonesia. Dispenda sesuai dengan berjalannya waktu serta perkembangan jaman yang telah memasuki teknologi informasi telah berkembang dengan sangat pesat, yaitu meningkatan kualitas pelayanan kepada wajib pajak dengan menggunakan teknologi informasi yang sangat canggih. Pelayanan pembayaran PKB telah dilakukan melalui berbagai kegiatan menggunakan komputer, mulai dari informasi sampai pada hasil produk akhir.
\end{abstract}

Kata kunci: Sanksi Administrasipelaksanaan Pajak Kendaraan Bermotor

\section{A. PENDAHULUAN}

Belajar tentang pajak dianggap rumit oleh kebanyakan orang. Hal ini disebabkan oleh jumlah peraturan perpajakan yang cukup banyak. Belajar pajak memerlukan pemahaman secara garis besar tentang pajak sebelum belajar mengenai detil-detil perpajakan. Pemahaman perpajakanan secara garis besar diharapkan dapat membantu menghadapi sebuah permasalahan apabila kkita dapat mengetahui pada posisi mana sebenarnya masalah perpajakan tersebut berada.

Dasar hukum paling utama bagi berlakunya pajak di Indonesia adalah Pasal 23A Undang-Undang 1945 (Amandemen IV) yang berbunyi, "Pajak dan pungutan lain yang bersifat memaksa untuk keperluan
Negara diatur dengan undang-undang". Itu berarti semua peraturan perpajakan haruslah menunjuk pada suatu undang-undang termasuk perangkat hukum di bawahnya sepanjang terdapat pelimpahan dari undangundang yang mengaturnya..

Pembangunan nasional yang dimana suatu kegiatan yang berlangsung secara terusmenerus dan berkesinambungan. Pembangunan tersebut bertujuan untuk mencerdaskan kehidupan bangsa dan kesejahteraan rakyat Indonesia secara adil, makmur dan merata. Agar tujuan tersebut dapat terwujud maka dibutuhkan dana, yang salah satunya berasal dari penerimaan pajak. Pajak merupakan pendapatan negara yang cukup potensial, untuk mencapai tujuan pembangunan nasional. Penerimaan dari 
sektor pajak ternyata salah satu sumber penerimaan terbesar negara. Negara akan maju kalau pajak tetap ada dan negara akan hancur kalau tidak ada pajak. Buktinya, kontribusi pajak dalam APBN sejak tahun 2010 sampai tahun 2014 terus meningkat. Pada tahun 2010 saja kontribusi pajak sudah $56,5 \%$, lalu tahun 2011 naik jadi $61,7 \%$, tahun 2012 menjadi 70,3\%, tahun 2013 menjadi 72,5\% dan tahun 2014 hampir mencapai 80\%, artinya bahwa kelangsungan hidup bernegara didominasi dan ditentukan dari besarnya penerimaan pajak. Dari tahun ke tahun terlihat bahwa penerimaan pajak terus meningkat dan memberi andil besar dalam penerimaan negara, oleh sebab itu penerimaan dari sektor pajak selalu dikatakan primadona dalam membiayai pembangunan nasional.

Peran fiskus dalam penerimaan pajak mempunyai andil besar sebagai pengawas wajib pajak dalam melaporkan dan membayar kewajiban perpajakannya guna mengurangi jumlah tunggakan pajak yang berpengaruh terhadap penerimaan pajak baik secara langsung maupun tidak langsung.

Pendapatan Daerah yang selanjutnya disebut PAD yaitu bersumber dari hasil pajak daerah, hasil retribusi daerah, dan hasil pengelolaan kekayaan daerah yang dipisahkan. PAD yang sah, bertujuan untuk memberikan keleluasaan kepada daerah dalam menggali pendanaan pelaksanaan otonomi daerah sebagai perwujudan asas desentralisasi. Berdasarkan Undang-Undang RI Nomor 28 Tahun 2009 tentang pajak daerah dan retribusi daerah. Pajak daerah terdiri atas pajak Propinsi dan pajak Kabupaten atau Kota. Pajak Kendaraan Bermotor (PKB) merupakan salah satu pajak Propinsi yang sejak tahun 1976 telah dipungut dengan mengguanakan Sistem administrasi manunggal satu atap (Samsat) yang menggabungkan pelayanan administrasi kendaraan bermotor dan pembayaran pajak dalam satu gedung.

Pembayaran pajak khususnya kendaraan bermotor diselenggarakan dengan mengingat keadaan negara dan masyarakat agar pembayaran Pajak Kendaraan Bermotor yang selanjutnya disebut dengan PKB, tepat waktu untuk alat pembuktian yang kuat sebagai warga negara yang taat membayar pajak. Wajib pajak membayar PKB bertujuan untuk memberikan kepastian hukum dan perlindungan hukum terhadap pemilik kendaraan yang sah selain mempunyai Surat Tanda Nomor Kendaraan yang selanjutnya disebut STNK.

Pembayaran PKB itu diwajibkan bagi pemilik kendaraan bermotor yang sah. Pembenahan pelayanan birokrasi yang selama ini cenderung dicitrakan jelek khususnya bidang perpajakan terus menjadi masalah baik ditingkat public atau wajib pajak maupun dilingkungan pemerintahan itu sendiri. Wajib pajak mempunyai tuntutan yang sangat kuat agar pemerintah konsisten untuk melaksanakan reformasi birokrasi dengan memberikan pelayanan prima kepada wajib pajak, sedangkan ditingkat pemerintahan 
sendiri, harus diakui pula bahwa secara legal formal pembenahan pelayanan pajak terus mendapat perhatian khusus.

\section{B. PEMBAHASAN}

Di dalam pembahasan kali ini penulis akan menjelaskan lebih jelas tentang Efektivitas Undang-Undang perpajakan terhadap pelanggaran pajak kendaraan bermotor ditinjau dari Undang-Undang Nomor 28 Tahun 2009 tentang pajak daerah dan retribusi daerah, yang dimana Istilah efektivitas berasal dari kata efektif yang mengandung pengertiandicapainya keberhasilan dalam mencapai tujuan yang telah ditetapkan.Efektivitas selalu terkait dengan hubungan antara hasil yang diharapkan dengan hasil yang sesungguhnya dicapai. Menurut Effendy menjelaskan Efektivitas adalah "Komunikasi yang prosesnya mencapai tujuan yang direncanakan sesuai dengan biaya yang dianggarkan, waktu yang ditetapkan dan jumlah personil yang ditentukan.”

Pengertian diatas mengartikan bahwa indikator efektivitas dalam arti tercapainya sasaran atau tujuan yang telah ditentukan sebelumnya merupakan sebuah pengukuran dimana suatu target telah tercapai sesuai dengan apa yang telah direncanakan. Berbeda dengan memberikan definisi tentang Efektivitas merupakan "daya pesan untuk mempengaruhi atau tingkat kemampuan pesan-pesan untuk mempengaruhi"
Pengertian sebagaimana dikemukakan oleh Susanto Azzhar tersebut, bisa diartikan sebagai "suatu pengukuran akan tercapainya tujuan yang telah direncanakan sebelumnya secara matang". Pendapat lain juga dikemukakan oleh Agung Kurniawan, dalam bukunya Transformasi Pelayanan Publik bahwa Efektivitas adalah "kemampuan melaksanakan tugas, fungsi (operasi kegiatan program atau misi) daripada suatu organisasi atau sejenisnya yang tidak adanya tekanan atau ketegangan diantara pelaksanaannya".

Efisiensi merupakan rasio output terhadap input, atau jumlah output per unit input. Dalam beberapa organisasi, efisiensi diukur dengan cara membandingkan biaya aktual dengan standar, dimana biaya-biaya tersebut harus dinyatakan dalam output yang diukur. Efisiensi dan efektivitas berkaitan satu sama lain,setiap pusat tanggung jawab dalam hal ini adalah organisasi, harus efektif dan efisien dimana, organisasi harus mencapai tujuannya dengan cara yang optimal. Suatu pusat tanggung jawab yang menjalankan tugasnya dengan konsumsi terendah atas sumber daya, mungkin akan efisien, tetapi jika output yang dihasilkannya gagal dalam memberikan kontribusi yang memadai pada pencapaian cita-cita organisasi, maka pusat tanggung jawab tersebut tidaklah efektif. Secara ringkas suatu pusat tanggung jawab akan bersifat efisien jika melakukan sesuatu dengan tepat, dan akan bersifat efektif jika melakukan hal-hal yang tepat. 
Berdasarkan Ensiklopedi Umum sebagaimana yang telah digariskan dalam Administrasi, efektivitas berasal dari kata kerja efektif, berarti terjadinya suatu akibat atau efek yang dikehendaki dalam perbuatan. Setiap pekerjaan yang efektif belum tentu efisien, karena mungkin hasil dicapai dengan penghamburan material, juga berupa pikiran, tenaga, waktu, maupun benda lainnya. Kata efektivitas sering diikuti dengan kata efisiensi, dimana kedua kata tersebut sangat berhubungan dengan produktivitas dari suatu tindakan atau hasil yang diinginkan. Suatu yang efektif belum tentu efisien, demikian juga sebaliknya suatu yang efisien belum tentu efektif. Dengan demikian istilah efektif adalah melakukan pekerjaan yang benar dan sesuai serta dengan cara yang tepat untuk mencapai suatu tujuan yang telah direncanakan. Sedangkan efisien adalah hasil dari usaha yang telah dicapai lebih besar dari usaha yang dilakukan.

Dari pengertian di atas, efektivitas dapat dikatakan sebagai keberhasilan pencapaian tujuan organisasi dari 2 (dua) sudut pandang. Sudut pandang pertama, dari segi 'hasil' maka tujuan atau akibat yang dikehendaki telah tercapai. Kedua dari segi 'usaha' yang telah ditempuh atau dilaksanakan telah tercapai, sesuai dengan yang ditentukan. Dengan demikian pengertian efektivitas dapat dikatakan sebagai taraf tercapainya suatu tujuan tertentu, baik ditinjau dari segi hasil, maupun dari segi usaha yang diukur dengan mutu, jumlah serta ketepatan waktu sesuai dengan prosedur dan ukuran-ukuran tertentu peraturan yang telah ditetapkan.

Untuk mencapai tujuan pemungut pajak perlu memegang teguh asas pemungutan dalam memilih alternatif pemungutannya. Maka terdapat keserasian pemungut pajak dengan tujuan dan asas yang masih diperlukan lagi yaitu pemahaman atas perlakuan pajak tertentu. Asas-asas pemungut pajak menurut Waluyo menyatakan bahwa pemungutan pajak hendaknya didasarkan pada :

1. Equality, Pemungutan pajak harus bersifat adil dan merata yaitu pajak dikenakan kepada orang pribadi yang harus sebanding dengan kemampuan membayar pajak atau ability to pay dan sesuai dengan manfaat yang diterima. Adil dimaksudkan bahwa setiap Wajib Pajak menyumbangkan uang untuk pengeluaran pemerintah sebanding dengan kepentingan dan manfaat yang diminta.

2. Certainty, Penetapan pajak itu tidak ditentukan sewenag-wenang. Oleh karena itu, Wajib Pajak harus mengetahui secara jelas dan pasti pajak yang terutang, kapan harus dibayar, serta batas waktu pembayaran.

3. Convenience, Kapan Wajib Pajak itu harus membayar pajak sebaiknya sesuai dengan saat-saat yang tidak menyulitkan Wajib Pajak, sebagai contoh pada saat Wajib Pajak memperoleh penghasilan.

4. Economy, Secara ekonomi biaya pemungutan dan biaya pemenuhan kewajiban pajak bagi Wajib Pajak 
diharapkan seminimum mungkin, demikian pula beban yang dipikul Wajib Pajak.

Untuk mencapai target penerimaan, Pemerintah telah melakukan berbagai perubahan diantaranya yaitu reformasi perpajakan (Tax Reform), langkah tersebut diawali pada tahun 1984. Program ini telah mengubah sistem perpajakan Indonesia, dari official assessment menjadi self assessment yang digunakan saat ini.

Agar pelaksanaan sistem self assessment dapat berjalan dengan baik, maka keterbukaan dan penegakan hukum (law enforcement) menjadi hal yang sangat penting. Disini peran aktif Wajib Pajak dalam melaksanakan kewajiban perpajakannya sangat diperlukan. Dengan kepercayaan dan tanggung jawab yang diberikan, diharapkan Wajib Pajak dapat melaksanakan hak dan kewajiban perpajakannya sesuai dengan peraturan perundang-undangan yang berlaku, dengan demikian peningkatan pendapatan negara dari sektor pajak dapat meningkat.

Memperhatikan pendapat para ahli di atas, disimpulkan bahwa efektivitas merupakan suatu konsep yang bersifat multi dimensional, artinya dalam mendefinisikan efektivitas berbeda-beda sesuai dengan dasar ilmu yang dimiliki walaupun tujuan akhir dari efektivitas adalah pencapaian tujuan. Kata efektif sering dicampur adukkan dengan kata efisien walaupun artinya tidak sama, sesuatu yang dilakukan secara efisien belum tentu efektif.
Berkaitan dengan pelaksanaan peraturan perundang-undangan, bahwa yang dimaksud dengan efektivitas pelaksanaan peraturan daerah adalah ukuran pencapaian tujuan yang ditentukan pangaturannya dalam peraturan daerah. Dengan demikian dapat dijelaskan bahwa efektivitas peraturan daerah diukur dari suatu target yang diatur dalam peraturan daerah, telah tercapai sesuai dengan apa yang ditentukan lebih awal. Guna mencapai tujuan tersebut maka perlu diperhatikan hal-hal sebagai berikut; rumusan peraturan perundang-undangan harus diterima oleh masyarakat, menjadi tujuan bersama masyarakat yaitu cita-cita kebenaran, cita-cita keadilan, dan cita-cita kesusilaan. Peraturan daerah juga harus sesuai dengan suatu paham atau kesadaran hukum masyarakat, harus sesuai dengan hukum yang hidup di masyarakat, serta harus mempunyai dasar atau tujuan pembentukan yang telah diatur sebelumnya dan atau ditetapkan pada peraturan yang lebih tinggi kewenangan berlakunya.

Jadi dengan adanya berlakunyaUndangUndang Nomor 28 Tahun 2009 tentang pajak daerah dan retribusi daerah, untuk menghidari pelanggaran pajak kendaraan bermotor termasuk dalam kategori efektif karena masyarakat pada uumnya banyak yang mematuhi atruran di dalam undang-undang tersebut. 


\section{PENUTUP}

Bentuk Sanksi terhadap pelanggaran pajak kendaraan bermotor ditinjau dari Undang-Undang nomor 28 tahun 2009 tentang pajak daerah dan pajak retribusi daerah yaitu berupa sanksi administrasi, yang berupa bunga/atau denda dan sanksi berupa pidana. Sanksi administrasi itu sendri di atur dalam pasal 1 ayat 59 Undang-Undang nomor 28 tahun 2009 tentang pajak daerah dan pajak retribusi dan sedangkan sanksi pidana itu sendiri diatur dalam pasal 174,176 dan 177 Undang-Undang nomor 28 tahun 2009 tentang pajak daerah dan pajak retribusi. Bentuk Efektivitas Undang-Undang perpajakan terhadap pelanggaran pajak kendaraan bermotor ditinjau dari UndangUndang Nomor 28 Tahun 2009 tentang pajak daerah dan retribusi daerah yaitu, yang dimana, dengan adanya berlakunyaUndangUndang Nomor 28 Tahun 2009 tentang pajak daerah dan retribusi daerah, untuk menghidari pelanggaran pajak kendaraan bermotor termasuk dalam kategori efektif karena masyarakat pada uumnya banyak yang mematuhi atruran di dalam undang-undang tersebut.

\section{DAFTAR PUSTAKA}

Achmad Tjahyono dan Triono Wahyudi. 2005. Perpajakan Indonesia Edisi Kedua. Jakarta : Raja Grafindo Persada, hal 43.

Azhar, Susanto. 2003. Sistem Informasi Manajemen. Edisi ke 2. Bandung : CV. Lingga Jaya.

Brotodihardjo, Santoso. 2004. Pengantar Ilmu Hukum Pajak. Bandung : Refika Aditama,

Kurniawan, Agung. 2005. Transformasi Pelayanan Publik. Yogyakarta: Pembaruan.

Siti Resmi, 2004, Perpajakan, Teori dan Kasus, Jakarta: Salemba Empat.

Mardiasmo. 2003. Perpajakan. Yogya:Andi Offset.

Wirawan B.Ilyas, Richard Burton. 2007. Hukum Pajak. Jakarta:Salemba Empat.

Undang-Undang Nomor 4 Tahun 1963 tentang Penetapan Peraturan Pemerintah.

Undang-Undang Nomor 3 Tahun 1965 tentang Lalu Lintas dan Angkutan Jalan Raya.

Undang-Undang Nomor 14 Tahun 1992 tentang Lalu Lintas Dan Angkutan Jalan.

Undang-Undang Nomor 22 Tahun 2009 tentang Lalu Lintas Dan Angkutan Jalan.

Undang-Undang Nomor 28 Tahun 2009 tentang Pejak Daerah dan retribusi Daerah.

Undang-Undang Nomor 3 Tahun 1963 tentang Sumbangan Wajib Istimewa. 